\title{
Signaling through CD40 Rescues IgE but Not IgG or IgA Secretion in X-linked Immunodeficiency with Hyper-IgM
}

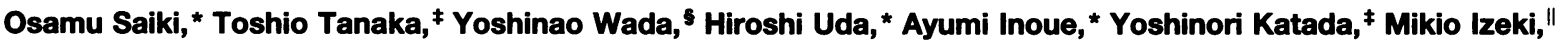 \\ Mayumi Iwata, ' Hiroyuki Nunoi, ' Ichirou Matsuda, ' Naokazu Kinoshita, ${ }^{*}$ and Tadamitsu Kishimoto* \\ *Department of Clinical Investigation of Osaka Minami National Hospital, 677-2, Kido-cho, Kawachi-Nagano City, Osaka 586 Japan; \\ ${ }^{\ddagger}$ The Third Department of Internal Medicine of Osaka University Medical School, 2-2, Yamada-oka, Suita-City, Osaka 565 Japan; \\ ${ }^{8}$ Research Institute of Osaka Medical Center for Maternal and Children, 840, Murodo-cho, Izumi-City, Osaka 590-02 Japan; \\ "Department of Pediatrics of Keio University Medical School, 35, Shinano-cho, Shinjuku-Ku. Tokyo 160 Japan; and 'Department of \\ Pediatrics of Kumamoto University Medical School, 2-2-1, Honjho-cho, Kumamoto-City, Kumamoto 860 Japan
}

\begin{abstract}
The ligand for CD40 (CD40L) is a membrane protein on activated $\mathbf{T}$ cells that induces $\mathrm{B}$ cell proliferation and differentiation. Several mutations of the CD40L gene were reported responsible for defective class switching of $B$ cells in an X-linked immunodeficiency with hyper IgM (X-HIM).

We studied four affected males from three families and found three independent mutations including new mutations of CD40L gene. In every X-HIM patient tested, however, anti-CD40 plus IL-10 did not induce class switching from IgM to IgG or IgA, even in the presence of Staphylococcus aureus Cowan I strain (SAC). CD4 + $T$ cell clones, expressing CD40L on their surface, also did not rescue IgG or IgA induction by X-HIM peripheral blood B cells in vitro. But signaling through CD40 induced both B cell proliferation and IgE secretion when IL-4 was added to the culture.

Taken together, these results show that in vitro signaling through CD40 rescues IgE but not IgG or IgA secretion by peripheral blood X-HIM B cells and suggest that in vivo CD40 and CD40L interaction might be necessary for IgG and IgA differentiation in X-HIM. (J. Clin. Invest. 1995. 95:510-514.) Key words: CD40 • IgE • B cell • IgM • immunodeficiency
\end{abstract}

\section{Introduction}

Immunodeficiency with hyper IgM (HIM) ${ }^{1}$ is a rare disorder characterized by recurrent bacterial infections associated with very low or absent IgG, IgA, and IgE and normal to increased IgM serum levels (1). Evidence for clinical heterogeneity has been provided by the demonstration that the HIM syndrome

Address correspondence to Osamu Saiki, M.D., Department of Clinical Investigation, Osaka Minami National.Hospital, 677-2, Kido-cho, Kawachi-Nagano City, Osaka 586, Japan. Phone: 721-53-5761; FAX: 72153-8904. 1994.

Received for publication 11 July 1994 and in revised form 7 October

1. Abbreviations used in this paper: $\mathrm{CD} 40 \mathrm{~L}$, ligand for CD40; CVI, common variable immunodeficiency; HIM, hyper IgM; SAC, Staphylococcus aureus Cowan I strain; Tc, T cell clone; TdR, thymidine; XHIM, X-linked immunodeficiency with HIM.

J. Clin. Invest.

(C) The American Society for Clinical Investigation, Inc.

0021-9738/95/02/510/05 \$2.00

Volume 95, February 1995, 510-514 can be either occur as a primary or as an acquired disorder (2, 3 ). Primary HIM is a very rare disease, which accounts for as little as $0.3-2.0 \%$ of all primary immunodeficiencies (4).

Several reported pedigrees are consistent with an X-linked inheritance. However, occurrence in females suggest that primary HIM syndrome can also be inherited as an autosomaldominant transmission $(1,3)$. Immune abnormalities in HIM syndrome are in most cases restricted to B cells with secretion of IgM only $(5,6)$. However, some patients have been reported with concomitant cellular immune defects resulting in a combined immune deficiency (7).

The CD40 cell surface antigen on B cells acts as a receptor capable of transmitting a signal $(8,9)$. The ligand for CD40 is a membrane glycoprotein on activated $\mathrm{T}$ cells and the recent isolation and characterization of cDNA clones encoding gp39 have made possible the detailed study of this receptor-ligand pair and it's role in B cell activation (10-12). A series of experiments have revealed that the signals delivered to $B$ cells via CD40 can synergize with other costimulatory signals to drive $B$ cell proliferation and differentiation (13-16). In XHIM patients, a series of recent papers reported that CD40L expression is incomplete on the surface of activated $T$ cells and the defect is due to several distinct mutations of the gene coding for CD40L (17-20). The resultant failure of CD40 and ligand interaction is suggested responsible for the Ig isotype switching defects. It is also reported that in vitro signaling through CD40 rescues not only IgE but also IgG and IgA production $(19,21)$

In the this study, we confirmed independent mutations of the CD40L gene among different X-HIM families. However, signaling through CD40 rescues only IgE production by patient's B cells, suggesting that further B cell defects might reside in this disease.

\section{Methods}

Patients. Four male HIM patients from three families participated in this study. Case 1 ( $3 \mathrm{yr}$ old) and 2 ( $7 \mathrm{yr}$ old) are brothers. Besides case 1 and 2, their mother and father and healthy brother ( $5 \mathrm{yr}$ old) also participated in this study. During the study, case 2 died of fungal meningitis at age 7. Case 3 ( $5 \mathrm{yr}$ old) and 4 ( $6 \mathrm{yr}$ old) are HIM patients from different families and all patients receive transfusion therapy of gamma globulin. Other X-HIM related patients, such as female HIM and common variable immunodeficiency (CVI) patients also participated in this study. A female HIM and two male type I CVI (22) patients whose B cells differentiate to only IgM secretion were examined.

Amino acid sequence analysis of genes coding for CD4OL. IL-2dependent $T$ cell lines from patients and EB virus transformed B cell lines were established by methods described elsewhere (23). Total RNA was extracted and reverse transcription of CD40L mRNA to cDNA was done according to standard methods using the primer for CD40L (19). 
The resulting product, which encompasses the entire coding region of CD40L (10), was cloned into Bluescript SK(+) and SK(-) (Stratagene, La Jolla, CA) using EcoRI-Sal sites incorporated in the two primers. To eliminate potential sequence artifacts caused by PCR, reverse transcription and PCR, and subsequent cloning of CD40L cDNA from activated cells of each patient, were done more than twice in independent experiments. For sequencing, at least 40 single clones were picked in every independent cloning experiment, pooled, and used for generation of single-stranded DNA. Entire CD40L coding regions were then sequenced manually.

Preparation of cells. Peripheral blood mononuclear cells (MNC) were separated by Ficoll-Hypaque (Pharmacia, Uppsala, Sweden) centrifugation of heparinized blood and were washed three times with RPMI 1640 (Nikken Bio Medical, Kyoto, Japan), as described previously (24). In some experiments, $T$ cells were removed by twice rosetting the cells with aminoethylisothiuronium bromide treated sheep blood cells and monocytes were partially depleted by a plastic adherent method (24). The remaining cell population, referred to as B cells, consisted of $>96 \%$ B cells $(\mathrm{CD} 20)$ and $<2 \%$ T cells $(\mathrm{CD} 3)$.

Reagents for $B$ cell stimulation. Usually $5 \mathrm{C} 3$ anti-CD40 mAb (Pharmingen, San Diego, CA) was used at concentration $1 \mu \mathrm{g} / \mathrm{ml}$ which induced the maximum Ig secretion in human $B$ cells. In some experiments, another anti-CD40 mAb (B-B20, $1 \mu \mathrm{g} / \mathrm{ml}$, Serotec, Kidlington, England) was used.

SAC, originally obtained from the National Collection of Type culture (London), was used. The bacteria were killed by incubation in $0.5 \%$ formaldehyde for $3 \mathrm{~h}$ at room temperature and then heat-killed at $80^{\circ} \mathrm{C}$ for $5 \min (25)$. The bacteria were harvested and washed three times with sterile saline and resuspended as a $10 \%$ stock solution in PBS. SAC was used at concentration $0.001 \% \mathrm{vol} / \mathrm{vol}(24)$.

Induction of immunoglobulin secretion. MNC $\left(10^{5} /\right.$ well $)$ were cultured in 96-well plates (Falcon, Oxnard, CA) in $200 \mu \mathrm{l}$ of RPMI 1640 supplemented with $10 \%$ FCS (Sterile Systems, Logan; UT), 2 mM glutamine. IL-10 (100 ng/ml; Genzyme Corp., Boston, MA) and IL-4 (Genzyme, $100 \mathrm{U} / \mathrm{ml}$ ) were added to the culture at the first day. Supernatants were harvested on day 14 and IgE concentration was determined by previously described enzyme linked immuno-sorbent assay (ELISA, 26) with some modification. In brief, microplates (Nunc-Immunoplate, Maxisorp, Denmark) were coated with $100 \mu \mathrm{l}$ of anti-human IgE antibody $(6-90,1 \mu \mathrm{g} / \mathrm{ml})$ over night at $4^{\circ} \mathrm{C}$. After blocking with $0.1 \%$ of BSA, a total volume $(100 \mu \mathrm{l})$ of diluted supernatant was assayed. After $2 \mathrm{~h}$ incubation at room temperature, alkaline phosphatase labeled antihuman IgE mAb (8-73) was added and incubated for $2 \mathrm{~h}$ at room temperature. After washing the wells four times, $100 \mu$ l of $p$-nitrophenyl phosphate substrate (Sigma Chemical Co., St. Louis, MO) solution was added to each well and absorbance at $405 \mathrm{~nm}$ was examined with an ELISA reader (ImmunoReader Nr-2000, InterMed). Purified IgE from IgE myeloma cell line U266 was used as the standard. IgM, IgG, and IgA secretion was also examined by isotype specific ELISA (Tago Inc., Burlingame, CA) as reported previously (24).

Preparation of CD4+ $T$ cell clones and cell culture. $T$ cells separated by $\mathrm{E}$ rosette formation were stimulated with PHA $(10 \mu \mathrm{g} / \mathrm{ml}$; Difco Laboratories Inc., Detroit, MI) and IL-2 (1 U/ml; Takeda, Osaka, Japan) every $4 \mathrm{~d}$. After limiting dilution, CD4+ clones were selected and expanded in Opti-MEM (GIBCO-BRL, Gland Island, NY) liquid medium supplemented with $10 \%$ FCS and further stimulated weekly with feeder cells (27). CD4 $+\mathrm{T}$ cell clones from a healthy brother express normal CD40L but those from case 1 express a mutation leading to a truncated CD40L (19). CD4+ T cell clones were irradiated at 3000 rad. and $2 \times 10^{5}$ cells were cultured in anti-CD3 (Leu 4, $100 \mathrm{ng} / \mathrm{ml}$; Becton Dickinson, Mountain View, CA) coated microculture plates.

Assay of $\left[{ }^{3} \mathrm{H}\right]$ Thymidine (TdR) Incorporation. MNC $\left(10^{5} /\right.$ well $)$ were cultured in 96-well, flatbottomed microculture plates (Falcon, Oxnard, LA) for $5 \mathrm{~d}$ and each culture was pulsed $\left[{ }^{3} \mathrm{H}\right] \mathrm{TdR}$ (DuPont-New England Nuclear, Boston, MA) for $4 \mathrm{~h}$. Subsequently, incorporation of $\left[{ }^{3} \mathrm{H}\right] \mathrm{TdR}$ was examined by a liquid scintillation counter $(24)$.

\section{Results}

Mutations in the coding region of CD4OL in HIM patients. RNA from HIM patients was reverse-transcribed into cDNA
CASE 1 and 2 and their family.

NA 462 TCT GTG TTA CAG TGG GCT GAA GAA 48

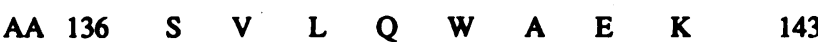
$475(G \rightarrow A)$

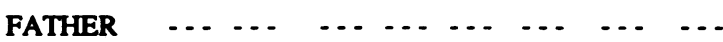

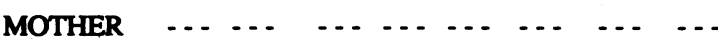

$\ldots \ldots-\ldots, \ldots-A-\ldots, \ldots, \ldots$

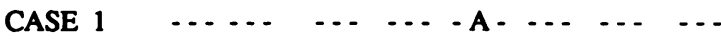

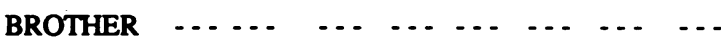

CASE $2 \quad \ldots \ldots \ldots \ldots \ldots$

TAG (stop codon, 140)

CASE 3

NA 753 CCA GGT GCT TCG GTG TTT GTC AAT 776

$\begin{array}{lllllllllll}\text { AA } & 233 & \text { P } & \text { G } & \text { A } & \text { S } & \text { V } & \text { F } & \text { V } & \text { N } & 240\end{array}$

CASE 3

$766(\mathrm{~T} \rightarrow \mathrm{A})$

GAG(GLU, 237)

CASE 4

NA 684 AAT ACC CAC AGT TCC GCC AAA CCT 70

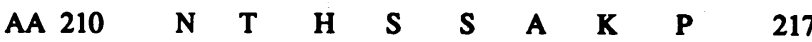

CASE 4

* deletion (692 C, 693 A)

G TTC CGC CAA ACC TTG

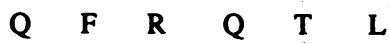

Figure 1. Mutations of CD40L gene in X-HIM Patients. Amino acid sequence analysis of genes coding for CD40L were examined in four male X-HIM patients, the father and mother of case 1 and 2, their healthy brother and HIM related patients. IL-2-dependent $T$ cell lines and $\mathrm{EB}$ virus transformed $\mathrm{B}$ cell lines were established and total RNA was extracted. Then entire cording region of CD40L was cloned and sequenced manually as described in Methods. In a female HIM and two male type I CVI (22) patients, no mutation was found.

and analyzed by PCR. Use of primers designed to copy the entire coding region of the PCR products of the CD40L gene transcripts showed normal length in all patients. The PCR-amplified cDNA of the CD40L coding region was then cloned into suitable vectors and fully sequenced in each case. Sequence analysis of cDNA obtained from brothers, case 1 and 2, revealed the same point mutation at nucleotide 475 (Fig. 1), turning the respective codon into a stop codon. This point mutation was reported to express a truncated CD40L on T cells (19). In a family study, the father and a healthy brother did not have the mutation, but the mother had an affected and an intact CD40 gene, which confirmed the X-linked trait. The cDNAs obtained from case 3 and 4 had new mutations. Case 3 had a point mutation at nucleotide 766 , resulting in an exchange of valine for glutamic acid, and case 4 had a deletion at 692-693. In a female HIM and two male type I CVI (22) patients, no mutation was found. These results confirm a series of papers (17-20) that the patients diagnosed X-HIM have several mutations in CD40L gene.

Induction of immunoglobulin secretion in MNC from HIM patients. Recently, anti-CD40 plus $\mathrm{IL}-10$ was reported to induce class switching from IgM to other isotypes of Ig in X-HIM patients $(19,21)$. MNC from X-HIM patients and a healthy brother of case 1 and 2 were stimulated with anti-CD40 (5C3) 
Table I. IgM, IgG, and IgA Induction by Anti-CD40 in X-HIM

\begin{tabular}{lcrrr}
\hline & Anti-CD40 + IL10 & IgM (ng/ml) & IgG & IgA \\
\hline Case 1 & - & 80 & $<50$ & $<50$ \\
& + & 1750 & $<50$ & $<50$ \\
& $+*$ & 2160 & $<50$ & $<50$ \\
Case 3 & - & 165 & $<50$ & $<50$ \\
& + & 3040 & $<50$ & $<50$ \\
Case 4 & - & 150 & $<50$ & $<50$ \\
& + & 1840 & $<50$ & $<50$ \\
Healthy* & - & 110 & 260 & 220 \\
Brother & + & 1650 & 5140 & 6700 \\
& & & & \\
\hline
\end{tabular}

MNC (10 $/$ well) were stimulated with $(+)$ or without (-) IL-10 plus anti-CD40 (5C3) for $14 \mathrm{~d}$ and IgM, IgG, and IgA secretion was examined by isotype specific ELISA. * Different anti-CD40 antibody (B-B20) was used. ${ }^{\ddagger}$ The healthy brother of case 1 (Fig. 1).

plus IL-10 for $14 \mathrm{~d}$ and Ig secretion was examined by Ig isotype specific ELISA. In the healthy brother's B cells, IgM, IgG, and IgA secretion was induced normally (Table 1). In HIM patients, however, IgG and IgA secretion was below detection although induction of IgM secretion was the same as that of healthy controls. When another lot of anti-CD40 (B-B20) was examined, production of IgG and IgA was also defective in case 1 .

The stimulation of SAC plus anti-CD40 and IL-10 was reported to induce maximum Ig secretion in X-HIM (19). Patients' MNC were stimulated by these B-cell mitogens for 14 d. In a healthy control, induction of IgG and A secretion was observed significantly (Fig. 2). In all four X-HIM patients tested, however, there was no induction of IgG and IgA secretion. Again induction of IgM secretion was as much as healthy controls. These results suggest that anti-CD40 antibody does not rescue IgG or IgA production in X-HIM B cells.

Stimulation of X-HIM B cells with CD4+ T cell clone. It is uncertain whether anti-CD40 antibody provides optional signals

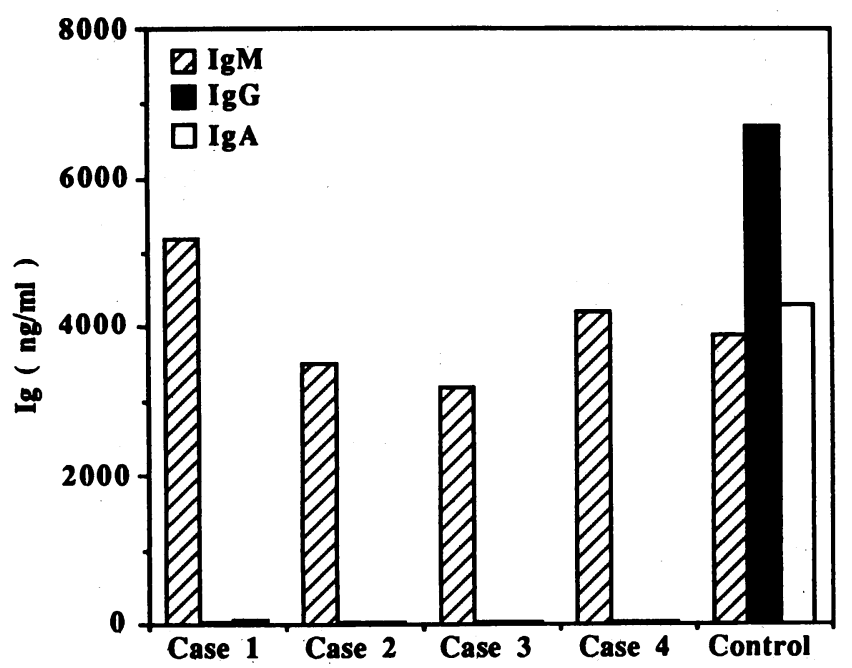

Figure 2. Induction of IgM, IgG, and IgA secretion by SAC in X-HIM. Peripheral blood MNC $\left(10^{5} /\right.$ well $)$ were stimulated with SAC $(0.001 \%$ $\mathrm{vol} / \mathrm{vol})$ plus anti-CD40 $(5 \mathrm{C} 3,1 \mu \mathrm{g} / \mathrm{ml})$ and IL-10 $(100 \mathrm{ng} / \mathrm{ml})$ for $14 \mathrm{~d}$. IgM, IgG and IgA secretion was examined by isotype specific ELISA.
Table II. Induction of Proliferation in X-HIM B Cells by Cd4+ T Cell Clones

\begin{tabular}{lcc}
\hline & B patient* & B brother $^{*}$ \\
\hline Medium & $394 \pm 41$ (c.p.m.) & $511 \pm 32$ \\
Tc brother & $4866 \pm 247$ & $7134 \pm 915$ \\
Tc patient* & $422 \pm 56$ & $614 \pm 49$ \\
anti-CD40 & $2140 \pm 185$ & $3327 \pm 416$
\end{tabular}

B cells were stimulated with irradiated $\mathrm{CD} 4+\mathrm{T}$ cell clones $(\mathrm{Tc})$ or anti-CD40 (5C3) in anti-CD3 coated culture plates. Tc brother expresses CD40L but Tc patient expresses a truncated CD40L (19). Data represent mean $\left[{ }^{3} \mathrm{H}\right]$-TdR incorporation $\pm \mathrm{SD}$ at day 5 of culture (c.p.m.). ${ }^{*}$ Case $1 \mathrm{X}$-HIM patient. ${ }^{\ddagger}$ The healthy brother of case 1 .

on interaction with CD40. In following experiments, B cells were stimulated with anti-CD3 activated CD4+ T cell clones instead of anti-CD40 antibody. It is reported that CD40L is preferentially expressed on activated CD4+ T cells (28). CD4+ $\mathrm{T}$ cell clones were prepared from case 1 and his healthy brother. B cells from case 1 and his healthy brother were stimulated with irradiated CD4+ T cell clones and examined for $\left[{ }^{3} \mathrm{H}\right] \mathrm{TdR}$ incorporation on day 5 of culture (Table II). CD4+ T cell clone from the healthy brother induced proliferation on both $\mathrm{B}$ cells significantly. However, CD4+ T cell clone from case 1 did not induce B cell proliferation at all. Anti-CD40, as a control, induced proliferation moderately on both $B$ cells. These results suggest that both CD40L and this anti-CD40 can activate XHIM B cells.

Induction of Ig secretion in X-HIM B cells by CD4OL. Further experiments were carried out to examine whether CD40L on CD4 $+\mathrm{T}$ cell clones can correct the defective IgG and IgA production in X-HIM (Table III). Irradiated CD4+ $\mathrm{T}$ cell clones and IL-10 were cultured with X-HIM B cells. The CD4+ $\mathrm{T}$ cell clone from the healthy brother induced not only IgM but also IgG and IgA production by his B cells. However, the same $\mathrm{T}$ cell clone failed to induce IgG and IgA production by the HIM patient's B cells. Even in the healthy brother's B cells, CD4+ T cells from HIM patient did not induce Ig secretion at all.

Table III. Induction of Ig Secretion by CD4+ T cell clones

\begin{tabular}{cccc}
\hline & $\operatorname{IgM}$ & $\operatorname{IgG}$ & $\operatorname{IgA}$ \\
\hline & & $n g / m l$ & \\
& & $<50$ & $<50$ \\
B bro. + med. & $<50$ & 3,340 & 1,840 \\
+ T bro. & 2,160 & $<50$ & $<50$ \\
+ Tc pat. & $<50$ & $<50$ & $<50$ \\
B pat. + med. & $<50$ & $<50$ & $<50$ \\
+ Tc bro. & 1,420 & $<50$ & $<50$ \\
+ Tc pat. & $<50$ & & \\
& & &
\end{tabular}

B cells from X-HIM patient and his healthy brother were stimulated with irradiated CD4+ T cell clones (Tc) and IL-10 in anti-CD3 coated culture plates for $14 \mathrm{~d}$. Ig secretion was examined by isotype specific ELISA. * CD4+ Tc from the healthy brother of case $1 .{ }^{\ddagger} \mathrm{CD} 4+\mathrm{Tc}$ from case $1 \mathrm{X}$-HIM patient. 


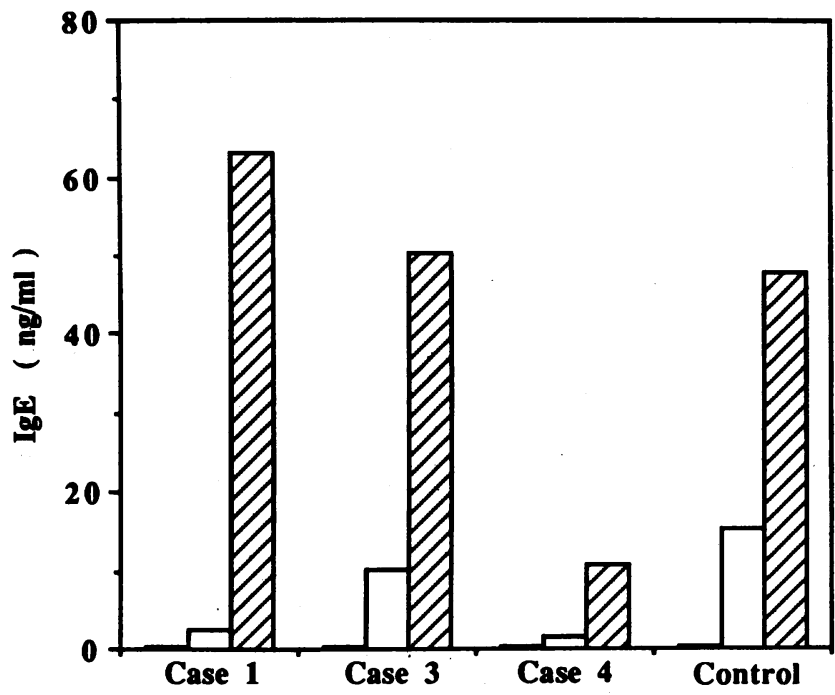

Figure 3. Induction of IgE secretion in X-HIM patients. Peripheral blood MNC ( $10^{5} /$ well) were stimulated with either anti-CD40 (5C3, $1 \mu \mathrm{g} /$ $\mathrm{ml}, \mathbf{\square})$, anti-CD40 plus $\mathrm{IL}-4(100 \mathrm{u} / \mathrm{ml}, \square)$, or anti-CD40 plus IL-4 and $\mathrm{IL}-10(100 \mathrm{ng} / \mathrm{ml}, \varpi)$, for $14 \mathrm{~d}$. At the end of culture, supernatants were harvested and IgE secretion was examined by ELISA.

These results suggest that $\mathrm{CD} 40 \mathrm{~L}$ does not correct defective IgG or IgA production in X-HIM B cells.

Induction of IgE production in X-HIM patients. In further experiments, IgE production was examined. MNC from X-HIM patients were stimulated by anti-CD40, IL-4, and IL-10 for 14 d and IgE secretion was examined by ELISA. Anti-CD40 plus IL-4 induced small amount of IgE production (Fig. 3). When IL-10 was added to the culture, anti-CD40 plus IL-4 induced significant IgE production in every patient tested. The amount of IgE production in X-HIM patient is as much as that of the healthy control. In contrast, anti-CD40 alone did not induce IgE secretion at all. These result show that production of IgE can be induced by cross-linking of CD40.

\section{Discussion}

In all X-HIM families examined, several mutations including new mutations of CD40L were confirmed. Recent studies on $\mathrm{X}$-HIM show that CD40L expression is incomplete and the defect is due to several mutations of genes coding for CD40L $(17-20,29)$. Our results support their finding that examination of the CD40L gene is critical for the diagnosis of X-HIM in contrast to other HIM and type I CVI whose B cells differentiate only IgM secreting cells (22).

The data of B cell function presented herein, however, are quite different from those of previous papers that describe signaling through CD40 rescues not only IgE but also IgG and $\operatorname{IgA}(18,19,21)$. In the present study, B cell defects of class switching for IgG and IgA were not rescued by any in vitro signaling through CD40 examined.

The reasons for the difference between former and present papers are not clear at present but several possibilities could be postulated. It is conceivable that the difference might be due to a different pattern of mutation in CD40L gene. However, in two patients (case 1 and 2), the same point mutation is found as in a patient T.G. (19). Even in a similar stimulation, such as anti-CD40 plus SAC and IL-10 (19), the defective IgG and IgA production could not be rescued in case 1 and 2 .

It is also conceivable that cross-linking of CD40 (5C3) did not provide sufficient signals for $B$ cell activation. We examined another anti-CD40 (B-B20), but the antibody did not correct the defective IgG or IgA production. Instead of anti-CD40, B cells were stimulated with CD40L on CD4+ $\mathrm{T}$ cell clones. Activated CD4 $+\mathrm{T}$ cell clones, reported to express preferentially CD40L on their surface (28), induced IgG and IgA production in normal B cells but not in X-HIM B cells. Normal CD4+ T cells and anti-CD40, however, induced both proliferation and IgE secretion in X-HIM B cells, suggesting that the signals provided through CD40 are adequate for this receptor and further that IgG and IgA production is defective in X-HIM B cells in vitro.

As for IgE induction, our results are well in accordance with former papers $(17-19,21,30)$. In the presence of IL-4, signaling through CD40 induces IgE secretion, suggesting that signaling through CD40 rescues IgE secretion in X-HIM. Hendriks et al. (31) show evidence that intrinsic Ig heavy chain class switch mechanism is intact in X-HIM. It is tempting to speculate that defective expression of CD40L would result in the inability to rearrange all Ig heavy chain genes downstream from the $\mu$ chain. In a healthy control, anti-CD40 plus IL-10 induces IgG and IgA but does not induce IgE production. IL4 , however, induced class switching for IgE preferentially, supporting the papers that IL-4 might be a in vitro switching factor specific for $\operatorname{IgE}$ and $\operatorname{IgG}_{4}(27,32)$.

It is also probable that in vitro signaling through CD40 may not provide adequate stimulation of class switching for IgG or IgA in peripheral blood X-HIM B cells. In another paper (33), we reported that sIgM+ peripheral blood B cells differentiate to IgM but not IgG or IgA secreting cells. In X-HIM, it is generally accepted that most of peripheral blood $\mathrm{B}$ cells bear IgM but not IgG or IgA on their surface $(21,30)$, suggesting that the defects of IgG and IgA production might be due to lack of sIgG and SIgA positive cells in peripheral blood. In case 1 , 3 , and 4 , sIgG and sIgA positive cells were $<1 \%$ (data not shown). Indeed the reason why $\operatorname{sigG}$ and $\operatorname{sIgA}$ positive cells are defective in X-HIM is not clear at present, but it is suggested that in vivo. CD40-CD40L interaction might be necessary for IgG and IgA switching in X-HIM patients who lack of germinal center (1).

We hope that these observations will provide the basis for further and more sophisticated delineation of immunoregulatory abnormalities in this disease.

\section{Acknowledgments}

We thank Dr. P. Ralph (Genentech) for critical review of the manuscript.

This work was supported in part by grant from the Ministry of Health and Welfare of Japan and the Osaka foundation for promotion of clinical immunology.

\section{References}

1. Notarangero, L. D., M. Duse, and A. G. Ugazio. 1992. Immunodeficiency with hyper IgM. Immunodefic. Rev. 3:101-122.

2. Schwaber, J., and F. S. Rosen. 1990. X chromosome linked immunodeficiency. Immunodefic. Rev. 2:233-251.

3. Puck, J. M. 1993. X-linked immunodeficiencies. Advances in human genetics. Plenum Press. New York. 21:107-144.

4. Lazi, G., L. Businco, and F. Aiuti. 1983. Primary immunodeficiency syndromes in Italy. J. Clin. Immunology. 3:316-321. 
5. Herrod, H. G., and R. H. Buckley. 1979. Use of a human plaque-forming cell assay to study peripheral blood bursa-equivalent cell activation and excessive suppressor cell activity in humoral immunodeficiency. J. Clin. Invest. 63:868876.

6. Levitt, D., P. Haber, K. Rich, and M. D. Cooper. 1983. Hyper IgM immunodeficiency: a primary dysfunction of B lymphocyte isotype switching. J. Clin. Invest. 72:1650-1656.

7. Mayer, L., S. P. Kwan, C. Thompson, H. S. Ko, N. Chiorazzi, T. Waldmann, and F. Rosen. 1986. Evidence for a defect in "switch" $T$ cells in patients with immunodeficiency and hyperimmunoglobulinemia M. N. Engl. J. Med. 314:409413.

8. Clark, E. A., and J. A. Ledbetter. 1986. Activation of human B cells mediated through two distinct cell surface differentiation antigens, Bp35 and Bp50. Proc. Natl. Acad. Sci. USA. 83:4494-4498.

9. Stamenkovic, I., E. A. Clark, and B. Seed. 1989. A B-lymphocyte activation molecule related to the nerve growth factor receptor and induced by cytokines in carcinomas. EMBO (Eur. Mol. Biol. Organ.) J. 8:1403-1410.

10. Graf, D., U. Korthauer, H. W. Mages, G. Senger, and R. A. Kroczer. 1992. Cloning of TRAP, a ligand for CD40 on human T cells. Eur. J. Immunol. 22:3191-3194.

11. Torres, R. M., and E. A. Clark. 1992. Differential increase of an alternatively polyadenylated mRNA species of murine CD40 upon B lymphocyte activation. J. Immunol. 148:620-625.

12. Armitage, R. J., B. M. Macduff, M. K. Spriggs, and C. Fanslow. 1993. Human B cell proliferation and Ig secretion induced by recombinant CD40 ligand are modulated by soluble cytokines. J. Immunol. 150:3671-3680.

13. Banchereau, J., P. de Paoli, A. Valle, E. Garcia, and F. Rousset. 1991. Long term human B cell lines dependent on interleukin -4 and antibody to CD40. Science (Wash. DC). 251:70-72.

14. Armitage, R. J., W. C. Fanslow, L. Strockbine, T. A. Sato, K. N. Clifford, B. M. Macduff, D. M. Anderson, S. D. Gimpel, T. DavisSmith, C. R. Maliszewski, E. A. Clark, C. A. Smith, K. H. Grabstein, D. Cosman, and M. K. Spriggs. 1992. Molecular and biological characterization of a murine ligand for CD40. Nature (Lond.) 357:80-82.

15. Rousset, F., E. Garcia, T. Defrance, C. Peronne, N. Vezzio, D. Hsu, R. Kastelein, K. W. Moore, and J. Banchereau. 1992. Interleukin 10 is a potent growth and differentiation factor for activated human B lymphocytes. Proc. Natl. Acad. Sci. USA. 89:1890-1893.

16. Hollenbaugh, D., L. S. Grosmaire, C. D. Kullas, N. J. Chalupny, S. Braesch-Andersen, R. J. Noelle, I. Stamenkovic, J. A Ledbetter, and A. Aruffo. 1992. The human $T$ cell antigen gp39, a member of the TNF gene family, is a ligand for the CD40 receptor: expression of a soluble form gp39 with B cell costimulatory activity. EMBO (Eur. Mol. Biol. Organ.) J. 11:4313-4321.

17. Allen, R. C., R. J. Armitage, M. E. Conley, H. Rosenblatte, N. A. Jenkins, N. G. Copeland, M. A. Bedell, S. Edelhoff, C. M. Disteche, D. K. Simoneaux, W. C. Fanslow, J. Belmont, and M. K. Spriggs. 1993. CD40 ligand gene defects responsible for X-linked hyper-IgM syndrome. Science (Wash. DC). 259:990993.

18. Aruffo, A, M. Farrington, D. Hollenbaugh, $X, \mathrm{Li}, \mathrm{A}$. Milatovich, $\mathrm{S}$. Nonoyama, J. Bajorath, L. S. Grosmaire, R. Stenkamp, M. Neubauer, R. L. Roberts, R. J. Noelle, J. A. Ledbetter, U. Francke, and H. D. Ochs. 1993. The
CD40L ligand, gp39, is defective in activated $\mathrm{T}$ cells from patients with $\mathrm{X}$-linked hyper-IgM syndrome. Cell. 72:291-300.

19. Korthauer, U., D. Graf, H. W. Mages, F. Briere, M. Padayachee, S. Malcom, A. G. Ugazio, L. D. Notarangelo, R. J. Levinsky, and R. A. Kroczek. 1993. Defective expression of T cell CD40 ligand causes X-linked Immunodeficiency with hyper-IgM. Nature (Lond.) 361:539-541.

20. Disanto, J. P., J. Y. Bonnefoy, J. F. Gauchat, A. Fischer, and G. de Saint Basile. 1993. CD40 ligand mutations in X-linked immunodeficiency with hyperIgM. Nature. 361:541-543.

21. Durandy, A., C. Suhiff, J. Bonnefoy, M. Forveille, F. Rousset, G. Mazzei, M. Milili, and A. Fischer. 1993. Induction by anti-CD40 or soluble CD40 ligand and cytokines of IgG, IgA and IgE production by B cells from patients with $\mathrm{X}$ linked hyper IgM syndrome. Eur. J. Immunol. 23:2294-2299.

22. Saiki, O., P. Ralph, C. Cunningham-Rundles, and R. A. Good. 1982. Three distinct stages of B-cell defects in common variable immunodeficiency. Proc. Natl. Acad. Sci. USA. 79:6008-6012.

23. Thorley-Lawson, D. A. 1980. The suppression of Epstein-Barr virus infection in vitro occurs after infection but before transformation of cells. J. Immunol. 124:745-751.

24. Saiki, O., M. Kawamoto, M. Fukuzumi, M. Kanou, and S. Utsumi. 1993. Staphylococcus aureus Wood 46 strain activates human B cell without affecting DNA synthesis or tyrosine phosphorylation. J. Immunol. 150:3324-3229.

25. Forsgen, A., A. Svedjejelund, and H. Wigzel. 1976. Lymphocytes stimulation by protein A of Staphylococcus aureus. Eur. J. Immunol, 6:207-210.

26. Suemura, M., and T. Kishimoto. 1985. Regulation of human IgE response by $\mathrm{T}$ cells and their products. Int. Arch. Allergy Appl. Immunol. 77:26-31.

27. Gascan, H., J. F. Gauchat, G. Aversa, P. V. Vlasselaer, and J. D. Vries. 1991. Anti-CD40 monoclonal antibodies or CD4 $+T$ cell clones and IL-4 induce IgG4 and IgE switching in purified human B cells via different signaling pathways. J. Immunol. 147:8-13.

28. Spriggs, M. K., R. J. Armitage, L. Strockbine, K. N. Clifford, B. M. Macduff, T. A. Sato, C. R. Maliszewski, and W. C. Fanslow. 1992. Recombinant human CD40 ligand stimulates B cell proliferation and immunoglobulin E secretion. J. Exp. Med. 176:1543-1550.

29. Narayanaswamy, R., R. Fuleihan, V. Ramesh, S. Lederman, M. J. Yellin, S. Sharma, L. Chess, F. S. Rosen, and R. S. Geha. 1993. Deletions in the ligand for CD40 in X-linked immunoglobulin deficiency with normal or elevated IgM (HIGMX-1). Int. Immunol. 5:769-773.

30. Fuleihan, R., N. Ramesh, R. Loh, H. Jabara, R. S. Rosen, T. Chatila, S. M. Fu, I. Stamenkovic, and R. S. Geha. 1993. Defective expression of the CD40 ligand in X chromosome-linked immunoglobulin deficiency with normal or elevated IgM. Proc. Natl. Acad. Sci. USA. 90:2170-2173.

31. Hendriks, R. W., M. E. M. Kraakman, I. W. Craig, T. Espanol, and R. K. B. Schuurman. 1990. Evidence that in X-linked immunodeficiency with hyper-immunoglobulinemia $\mathbf{M}$ the intrinsic immunoglobulin heavy chain class switch mechanism is intact. Eur. J. Immunol. 20:2603-2608.

32. Shapira S. K. D. Vercelli, H. H. Jabara, S. M. Fu, and R. S. Geha. 1992 Molecular analysis of the induction of immunoglobulin $\mathrm{E}$ synthesis in human B cells by interleukin 4 and engagement of CD40 antigen. J. Exp. Med. 175:289292.

33. Saiki, O, and P. Ralph 1982. IgM- and IgD-bearing peripheral blood lymphocytes differentiate to IgM but not IgG or IgA immunoglobulin-secreting cells. Eur. J. Immunol. 12:506-510. 